\title{
In Conversation
}

\author{
Daphne Marlatt, Kathy Mezei, Gail Scott, \\ Susan Knutson, Barbara Godard
}

D.M. What is it about the word 'conversation' that appeals to my imagination so much more than 'discussion' or 'dialogue'? Perhaps it's a less formal connotation, an association with the spoken rather than the written word. From the Socratic dialogues on, dialogue, like discussion, has tended to be associated with the written treatment of certain ideas (taking good philosophic medicine), exercising one's intellect - on whatever. As for whatever, she, to appropriate the generic, has had little to say in this case because the case he has made out for her is already closed. On the other hand, conversation elicits her participation, creates an opening for her to speak: to beg the question if she so desires, to reword it, return it, transformed by her own perspective. The mutual quality of conversation is embedded in its very roots, in Middle English, Old French, in Latin to live with, and further back (Indo-European), to turn. Two minds turning around each other, two (at least) perspectives, two (various) entries into language turning over the words, testing them, trying them on for size in a mutual exchange that wanders from room to room, takes breaks, remakes the linguistic bed, stirs diversion into analysis. In d'elles, Suzanne Lamy, writing about the woman-to-woman series of interviews between Marguerite Duras and Xavière Gauthier, stressed the 'betweenness' of their entretiens, their mutual listening and questioning that ran so counter to the monologues déguisés of interviews with male writers. She observed that the interviews quickly shifted to Duras' home, with the women making jam together between conversations. In the nearly ten years since d'elles' appearance, have we seen women's writing in Québec and Canada create the kind of space in which women readers can feel at home? Are we talking back and forth to each other - in the play of intertextuality, for instance, do we have an extended conversation? Or is this a closed conversation, limited to only a few writers? And what about the openness, the exploring quality of conversation, as opposed to the monologic - can this be said to signal feminist 


\section{Tessera}

writing? Or are we moving towards an orthodoxy, a closed system of ideas?

K.M. Dialogue is seen as a structured form with conventions and expectations, 'to speak alternatively.' Because of Bakhtin's theories of the dialogic imagination, it is now a fashionable term, whose perimeters have expanded to include (covert) relationships within and without texts; everything is in a dialogic relation with everything, and if not, that is significant too. A dialogue surely implies an oral activity, but as you mentioned, Daphne, it is associated with the written-in the structured debates of Socrates and Plato (and were they not really monologues, lectures, yes, a method of teaching, but of conveying and imposing a master's point of view? which accounts for Louky Bersianik's rewriting of Plato's symposium in Le pique-nique sur $l^{\prime}$ Acropole), and in the writing down of conversations between people in novels, i.e. the dialogue in Jane Austen or Margaret Atwood, or Ernest Hemingway! What happens in the writing down, what shifts, changes, omissions, erasures? Who writes the dialogue? The speakers or a listener? Perhaps then Daphne is right in seeing dialogue as too bound up with patriarchal discourse in which women have been silenced (and what of Diotima in Plato's Symposium?). Are the pieces you will read in Tessera dialogues - two voices speaking alternatively - but in prescribed modes? Are there among them feminist rewritings of this genre? Or are the interviews conversations rather than dialogues? But conversations, Daphne, are not exchanges only between two voices, but between many, like the first Tessera editorial, and like this editorial. But then what prevents women from interrupting the other, from monologuing, from truly hearing the other voices? And now I think I am repeating your questions: how can the writing express the opening, the liberating, and the building that conversation among women, free from censors and the observing eye, and accompanied by good food and wine should 'ideally' exemplify? Are the plays of Jovette Marchessault conversations among women, or are they a series of monologues? Where are the conversations in the fictions you read, or are they still trapped in silence and absence? Can conversations carry us further into new ideas? Do we listen to each other? Look at the words; look at the syntax of our speaking.

G.S. Comparing dialogue and conversation seems like comparing apples and oranges, given that their borders fade and cross, particularly in women's writing where the spoken and written word have moved closer together. It's true dialogue refers more directly to the 


\section{In Conversation · 9}

text, to writing. And since dialogue seems to be on the way here to getting a bad name, I think I'll play devil's advocate and defend it. Perhaps the reference to the Socratic notion of dialogue has inadvertently set us off on assumptions that I believe are no longer valid (notably that it is a male discourse tending towards closure, hence excluding her intervention). In fact, contemporary women writers, including Kristeva and Lamy have feminized the notion of dialogue rather than rejecting it.

I personally love how new writing by women strives to situate the reader in a participatory stance that I would call dialogique vis-à-vis the text, by assuming she the writer is addressing a feminine other. This stance assumes theory as a collective process - the opposite of what goes on in academia. In the writing group to which I belong, for example, we set ourselves the goal of fruitful dialogue in the first part of our meetings: the 'coffee' part. That's when we discuss the texts we've brought with us, always texts on some theoretical point of mutual interest. (This issue carries the texts of a meeting on feminism and post-modernism.) And I, for one, would be very annoyed if our discussions were interrupted by 'conversation' about domestic matters, love affairs, etc. except inasmuch as these matters touched on the subject at hand. The conversation comes after the work. I guess dialogue is about rigour, and I don't see why feminists should do without this kind of concentration, this means of striving for excellence.

I don't mind, either, that the modern notion of dialogue comes from Bakhtin, because Bakhtin's theories of transgressing the law by abolishing the writer-as-unary-authority were developed in the context of revolutionary struggle. In turn, the women's struggle has added a new ideological slant to the notion, underscoring the transgressive nature of writing as a dialogue among women that modifies both the writing and the reading (and the writer and the reader). Constantly. I believe so firmly in the energy of this struggle and how it feeds our writing, and the reverse, that I do not fear we are a few women talking to each other. For me, also, the dialogic has to be profoundly anchored in form to work: it must be writing that cries for response through each of its spaces, its provocations, its theoretical questioning. It doesn't preach, teach, provide the correct feminist line. That's why I prefer l'écriture au féminin to feminist writing. I just wish I could find a good English translation for the former - writing-in-the-feminine seems to dilute it somehow ...

S.K. In 'musing with mothertongue,' Daphne wrote of language 
that 'it bears us as we are born in it, into cognition.' What is true of language is particularly true of discourse. In discourse, whether conversation or dialogue, we are created and cradled, given back to ourselves in the intimacy of connection between the first and second person: the I and the other-to-whom-I-speak(s). I talk(s) to you and you answer(s) in a rise and fall that is not transcendance but two subjects swimming in 'our sea' ('musing with mothertongue'), splashing the swelling surface of our being in words. We are born each singly but together. We exchange gifts.

In discourse between women a warmth can arise from the fact that we are symbolic equals. Women's shared symbolic status as 'the other sex' inhibits the automatic exercise of rank that gender hierarchy makes possible. This gives us a chance to deal with issues of privilege which do divide us, including those of race, class, nationality, disability and sexual preference. My feminism hopes and believes that gender can be a bridge of listening and solidarity between women with different experiences of oppression and privilege.

In the world which is opened up by the feminine I and you addressing each other, women are constructed as subjects. We feminize the two true personal pronouns that are the 'Devonian rocks' of IndoEuropean languages and the bedrock of our subjectivity.* Emile Benveniste has shown how the first person and second person pronouns indicate positions in discourse, functioning referentially to construct subjectivity. 'She,' 'he' and 'it,' on the contrary, point to one who is absent: signifying what is outside the spiral of discourse, they are not true pronouns. Monique Wittig pursued the implications of Benveniste's argument for women ('The Mark of Gender'). She declared that in spite of gender's marking of women as other, we 'lay claim to universality' 'through abstraction' when, at the moment of speech, we assume the powers of language. This theory parallels the moment of holographic illumination in Nicole Brossard's Picture

* The personal pronouns belong to the very earliest layer of Indo-European that can be reached by reconstruction; they have been called the Devonian rocks' of Indo-European. The lack of any formal resemblance in English between the subject case (nominative) I and the object case (accusative) me is a direct and faithful reflex of the same disparity in Proto-Indo-European, respectively ${ }^{*} e g\left({ }^{*} \mathrm{ego}\right)$ and ${ }^{*} m e-1$. The other pronouns are ${ }^{*} t u$ - ("te-), 'thou,' *nes-2, *we-, 'we,' *yu-1 ("wes-), 'you.' No pronouns for the third person were in use. (Calvert Watkins, Indo-European and the Indo-Europeans,' The Houghton Miffin Canadian Dictionary of the English Language, p. 1499.) 


\section{In Conversation $\cdot 11$}

Theory: le scène blanche from which surges forth a picture of la femme intégrale. In accessing the utopian potential of language we position ourselves in respect to that powerful abstraction, and become what we really are, whole and integral. We also position ourselves with respect to the world we are addressing.

Building culture au féminin we inhabit not only the ' $\mathrm{I}$ ' and the 'you' but the 'she,' 'he' and 'it' for the construction of world in which women live fully. Attentive, as Daphne says, to each other's turnings.

B.G. The collective form which our conversation takes in this introduction, as well as that of Louky, France, Gail, Nicole and the Louises occurring on the theoretical Sundays, has been identified as a form of exchange privileged by women in the form of helpful interchange which Jeanne Demers and Line McMurray have found in the graffiti of women prostitutes in Montreal. You all know the form in women's washrooms. One woman asks a question (often implicit) and others provide a string of responsive and serious replies. This 'collectiveconversation' is advisory, interactive, caretaking - and unique to women's graffiti. However, Bruner and Kelso conclude, this is a form of support for one another in opposition to the dominant patriarchal order, an expression of the co-operation of the dominated. As such, this model of collaborative and empowering talk may itself be encoded within the power politics of sexual difference, that is, within the dominant discourse, as absence and not as resistance or struggle. In this way, I circle around the issue which concerns us all, the question of power and feminist struggle. Power is a word we more frequently address indirectly through a series of questions. What is the difference between dialogue and conversation? Is it a difference between male hierarchical writing and female egalitarian speaking? What are the implications of such binary thinking?

This is where Bakhtin becomes helpful, as you point out, Gail, in underscoring the transgression of the law in his concept of the dialogic or the carnivalesque (which sounds more subversive). We have to be careful though not to equate dialogue with dialog, or the dialogic, as Bakhtin more frequently terms it, the juxtaposition or confrontation of languages, of social forces and epochs, determined by the socioideological development of languages. Nor is dialogic a synonym for dialectic. Dialectic is abstract and moves towards synthesis whereas dialogic is material and exists only for another contextual meaning in an infinitely continuing chain of meaning. The blurring of boundaries in the interrelation between the inserted speech of the other and one's 
own speech produces a new subject position, not a unitary subject, 'Ifor-myself,' but a heterogeneous subject, 'I-for-another' and the 'notI-in-me.' In this concept of relational difference, the dialogic contrasts with the hierarchical ordering of difference in/by discourse, according to Foucault, for whom discourse focuses primarily on how power dominates by prescribing reversals, reverse discourses and counterdiscourses. Power may also be productive, as Bakhtin points out. Rather than locating resistance as merely a counter-effect of the networks of power, one may also begin from a situation of struggle, radi$\mathrm{cal}$ action and change. Meaning exists differentially. No practice or discourse exists in itself; on whatever side, it is ultimately shaped and preceded by what it is opposing and so can never simply dictate its own terms.

The importance of the dialogic for feminist discourse becomes clear. It establishes a theoretical ground for an emancipatory practice grounded in critique and resistance. For the focus of the dialogic is on becoming and change, on bodies and social formations as s(c)ites of transgression. In these terms, the feminist project is not merely inscribed within the dominant discourse as opposition but is an independent movement toward empowerment. In Bakhtin's notion of a field of clashing languages - heteroglossia - (his word for discourses) is to be found an instance of popular discourses taking shape both against and from beyond the terrain of what prevails. Moreover, Bakhtin acknowledges that all our thought - philosophical, scientific, and artistic - is born and shaped in the process of interaction and struggle with others' thought which foregrounds the transformative impact of confrontation. Like you, Gail, I take heart in the energy of this struggle, energy whose transformative capacities feed not only our writing but also our reading.

'The only complete reading is the one which transforms the book into a simultaneous network of reciprocal relationships,' writes Derrida. Now that I have transformed your texts by reading them intra and intertextually with respect to subjectivity and discourse, Tesserae, it is the reader's turn to exercise her transformative capacities. Since reading one text through another, the palimpsest, is the paradigm for allegorical work, my (re)writing is a form of allegoresis, a practice that is an investigation of speaking bodies and tell-tale signs, that is, a performative gesture, calling you. 